\title{
Optimization of Irrigation Level for Selected Sugarcane Varieties in AEZ -11 of Bangladesh
}

\author{
M. A. Rahman ${ }^{1}$, S U. K. Eusufzai ${ }^{1}$, S. S. Tabriz ${ }^{1}$ and S. M. I. Hossain ${ }^{2} *$ \\ ${ }^{1}$ Bangladesh Sugarcane Research Institute, Ishurdi, Pabna, Bangladesh \\ ${ }^{2}$ Dept. of Agricultural Engineering, BSMRAU, Gazipur-1706, Bangladesh \\ *Corresponding author: hossain_smi@yahoo.com
}

\begin{abstract}
An experiment was conducted in a farmer's field at Loknathpur in Chuadanga district under AEZ-11 (high ganges river floodplain) during 2005-06 and 2006-07 to determine the optimum irrigation level for the best performance of four sugarcane varieties (Isd 16, Isd 32, Isd 34, Isd 35). The experiment was laid out in two factors split-plot design with four irrigation levels in main plots and four varieties in sub-plots. Extra irrigations at 21, 28 and 35 days interval in addition to two live irrigations increased sugarcane yield from 15 to $48 \%$. All the varieties showed higher establishment, tiller, millable cane and cane yield when irrigations were applied at 28 days interval over irrigation at 21 or 35 days interval. Variety Isd 32, Isd 34 and Isd 35 produced significantly higher yield. However, the overall performances of all of the selected varieties were satisfactory. These varieties can be cultivated for potential yield in sandy loam soil under AEZ-11 providing 5 irrigations at 28 days interval in addition to two live irrigations at 0 and 14 days after transplantation when soil bed budchip settlings are used as planting materials.
\end{abstract}

Keywords: Sugarcane, optimization, irrigation, variety.

\section{Introduction}

Irrigation is a scarce and important input for sugarcane cultivation in Bangladesh. Inadequate or excess water supply is invariably a constraint to growth and yield of sugarcane in the world. For proper plant growth and yield, sugarcane needs about $1260 \mathrm{~mm}$ of rain water or equivalent irrigation (Shih et al.,1977). In areas of low or unreliable rainfall or where the rainfall is not evenly distributed throughout the year the crop is to be irrigated. Sugarcane has a high water use efficiency than other crops. It has been found that 200-250 tons of water is required to produce one ton of sugarcane (Anon., 1987).

Sugarcane production in Bangladesh suffers fluctuations because of uneven distribution and shortage of rainfall. Yearly rainfall starts from the month of April and continues to October. However, more than 60 percent of the total rainfall concentrates in the month of June, July and August, causing water stagnation in the field. This results oxygen stress in the root zone of sugarcane and loss of yield and reduction of quality. During the rest of the months from November to March, the rainfall is very scanty and erratic (Hossain, 2008). In some of these months there occurs no rainfall at all; whereas plantation, germination and tiller formation of sugarcane mainly take place during these dry months. Sugarcane, thus, in these months needs adequate moisture level to promote successful germination, tillering and growth of the crop. It is reported that yearly 2 to 3 irrigations during November to March increased sugarcane yield by $30 \%$ or more (Hossain, 1992). Irrigation 
required at field condition in the sandy loam soil is about $10 \mathrm{~cm}$ (Michael, 1991).

However, excess water use may induce leaching of nutrients beyond root zone and may also create oxygen stress and therefore, may retard growth of plants instead of boosting yield. Sugarcane, in general, grows well up to soil moisture retention range of $0.2-2.5$ bars in arid climates and about 1.8 to 2.5 bars in humid climates. Generally, the percent aeration porosity even after irrigation should not go down below 10\% (Husz, 1972 as cited by Srivastava and Singh, 1987).

On the other hand, all varieties of sugarcane do not respond to water stress similarly. Some varieties can withstand more water stress than others and may produce better yield even in drought condition. In contrast, some varieties can produce better yield in water stagnation condition. Besides, a particular variety of sugarcane doesn't show the same performance in the different soil and climatic conditions.

North and north-west regions (AEZ-1, 3, 11 etc.) are the potential areas for sugarcane and almost all the sugar mills are concentrated in these regions. Usually dry climate prevails in this area with low rainfall and high temperature during the summer. Supplementary irrigation may promote yield of sugarcane in this area. An experiment was therefore, conducted at Loknathpur under Chuadanga district (AEZ-11) to determine the optimum irrigation level for the best performance of some selected sugarcane varieties.

\section{Materials and Methods}

\subsection{Location and Treatments}

The study was carried out in a farmer's field at Loknathpur under Chuadanga Sub-station of Bangladesh Sugarcane Research Institute (BSRI) in AEZ-11 with four sugarcane varieties viz. Isd 16, Isd 32, Isd 34 and Isd 35 during 2005-06 and 2006-07. Settlings were raised from budchips of these varieties in soil bed. At the age of 42 to 56 days, the settlings were transplanted in the main field. The experiment was laid out in split-plot design with four irrigation treatments in the main plots and four sugarcane varieties in the subplots as given in Table1 and was replicated thrice. The plot size of the experiment was $6 \mathrm{~m} \mathrm{x}$ $5 \mathrm{~m}$. The soil of the experimental field was sandy loam with $\mathrm{P}^{\mathrm{H}}$ value ranged from 6.1 to 7.5. In the sub-plot, budchip settlings were transplanted at a rate of 75 settlings per plot (25000 settlings per hectare).

Fertilizers were applied as per BARC recommendation (BARC, 1989) and intercultural operations were done as per BSRI recommendation (Rahman et al., 1998). The total number of tillers and millable canes produced in each plot were counted and converted into number per hectare. The numbers of tillers produced by different varieties in different irrigation treatments were counted during May 2006 after 6 months of transplantation and the numbers of millable canes were counted just one week before harvesting. Yield of sugarcane was determined during harvesting at the last week of January.

\subsection{Irrigation Applied}

Number and time of irrigation for different treatments during 2005-06 and 2006-07 are given in Table 2 .

Two live irrigations were applied to all treatments at 0 and 14 days after transplantation. From the previous experience it was essential to apply at least two irrigations at 0 and 14 days after transplantation for soil bed settlings (Hossain, 2008). Irrigation treatments $I_{1}, I_{2}, I_{3}$, and $\mathrm{I}_{4}$ received a total of $2,7,7$, and 6 irrigations, respectively. The higher number of irrigations was applied to treatment $I_{2}$ and $I_{3}$ where irrigation was applied at 21 and 28 days interval. During each of the first two live irrigations, $6 \mathrm{~cm}$ water was applied as a sallow irrigation. However, in the latter irrigations, water was applied at a depth of $10 \mathrm{~cm}$ each. The depth of water applied was measured by measuring the flow of water in the channel during irrigation. 
Table 1. Main plot and sub-plot treatments of the experiment laid in split-plot design.

\begin{tabular}{ll}
\hline \multicolumn{1}{c}{$\begin{array}{c}\text { Main-plot treatment } \\
\text { (Irrigation) }\end{array}$} & \multicolumn{1}{c}{$\begin{array}{c}\text { Sub-plot treatment } \\
\text { (Variety) }\end{array}$} \\
\hline $\mathrm{I}_{1}=$ Life irrigation at 0 and 14 days after plantation & $\mathrm{V}_{1}=$ Variety Isd 16 \\
$\mathrm{I}_{2}=\mathrm{I}_{1}+$ irrigation at 21 days interval & $\mathrm{V}_{2}=$ Variety Isd 32 \\
$\mathrm{I}_{3}=\mathrm{I}_{1}+$ irrigation at 28 days interval & $\mathrm{V}_{3}=$ Variety Isd 34 \\
$\mathrm{I}_{4}=\mathrm{I}_{1}+$ irrigation at 35 days interval & $\mathrm{V}_{4}=$ Variety Isd 35 \\
\hline
\end{tabular}

Table 2. Number and day of irrigation application for different treatments during 2005-06 and 200607 (planted on December 23, 2005 and 2006).

\begin{tabular}{lcccc}
\hline & \multicolumn{4}{c}{ Treatment } \\
\cline { 2 - 5 } & $\mathrm{I}_{1}$ & $\mathrm{I}_{2}$ & $\mathrm{I}_{3}$ & $\mathrm{I}_{4}$ \\
& $(2$ live & $(21$ days & $(28$ days interval $)$ & $(35$ days interval) \\
\hline irrigations $)$ & interval $)$ & & \\
No. of irrigation & 2 & $2+5=7$ & $2+5=7$ & $2+4=6$ \\
Irrigation applied after & 0,14, & 0,14, & 0,14, & 0,14, \\
plantation (DAP) & & 35, & $42,70,98,126$, & $49,84,119,154$ \\
Total irrigation water & 12 & $56,77,98,119$ & 154 & 52 \\
$(\mathrm{~cm})$ & & 62 & 62 & \\
\hline
\end{tabular}

\section{Results and Discussion}

\subsection{Establishment of settling}

Establishment of budchip settlings as influenced by irrigations is shown in Table 3 . The highest average establishment was found in treatment $I_{3}$ $\left(23.39 \times 10^{3} \mathrm{ha}^{-1}\right)$ followed by treatment $\mathrm{I}_{4}(23.26$ x $\left.10^{3} \mathrm{ha}^{-1}\right)$ and $\mathrm{I}_{2}\left(23.14 \times 10^{3} \mathrm{ha}^{-1}\right)$ during 200506 . The lowest average establishment was found in treatment $\mathrm{I}_{1}\left(22.55 \times 10^{3} \mathrm{ha}^{-1}\right)$ where no irrigation was applied except two live irrigations.

However, during 2006-07, highest average establishment was found in both $\mathrm{I}_{3}$ and $\mathrm{I}_{4}(23.72$ x $\left.10^{3} \mathrm{ha}^{-1}\right)$ followed by $\mathrm{I}_{2}\left(23.63 \times 10^{3} \mathrm{ha}^{-1}\right)$. The lowest average establishment was found in $\mathrm{I}_{1}$ $\left(23.18 \times 10^{3} \mathrm{ha}^{-1}\right)$. In $\mathrm{I}_{1}$ treatment during 2005-06, there was no rainfall in the month of January, February and March while during 2006-07, there was $119 \mathrm{~mm}$ rainfall in the month of February and $37 \mathrm{~mm}$ in March. So, the average establishment in $\mathrm{I}_{1}\left(23.18 \times 10^{3} \mathrm{ha}^{-1}\right)$ during 2006-
07 was higher than during 2005-06. It is revealed from Table 3 that during both 2005-06 and 2006-07, highest establishment was found in treatment $\mathrm{I}_{3}$ or $\mathrm{I}_{4}$ and the lowest was in treatment $I_{1}$, which clearly indicates the influence of irrigation on establishment of settlings.

The establishment of settings of different varieties at different irrigation levels is shown in Figure 1 and 2 for 2005-06 and 2006-07, respectively. The differences in establishment of different varieties in different irrigation treatments were not significant. However, the highest establishment of settlings was found in all the varieties under treatment $\mathrm{I}_{3}$ during 200506 (Figure 1). On the other hand, during 200607, the highest establishment of settlings was found in varieties $V_{1}$ and $V_{2}$ under treatment $I_{3}$ and $\mathrm{I}_{4}$, while those in varieties $\mathrm{V}_{3}$ and $\mathrm{V}_{4}$ under treatment $\mathrm{I}_{2}, \mathrm{I}_{3}$ and $\mathrm{I}_{4}$ (Figure 2). 


\subsection{Number of Tiller}

It is evident from Table 3 that during 2005-06 and 2006-07 the average number of tillers produced in treatments $\mathrm{I}_{2}, \mathrm{I}_{3}$ and $\mathrm{I}_{4}$ where 5,5 and 4 extra irrigations were applied, was significantly higher than that of the control treatment $\mathrm{I}_{1}$, where only two live irrigations were applied. During 2005-06, the highest number of tillers was produced in treatment $\mathrm{I}_{3}(152.30 \mathrm{x}$ $\left.10^{3} \mathrm{ha}^{-1}\right)$, although the differences were not significant and the lowest number of tillers was produced in treatment $\mathrm{I}_{1}\left(123.45 \times 10^{3} \mathrm{ha}^{-1}\right)$
(Table 3). Similar effect was also observed during 2006-07 cropping seasons. These evidences have reconfirmed the fact that application of irrigation significantly increases the number of tillers. The same trend of increased tiller with irrigation has been reported by Hossain (2008). Number of tillers also depends on the variety as it is the inherent characteristics. So, at the same input level and environmental condition all varieties did not produce same number of tillers.

Table 3. Effects of irrigation on yield and yield parameters of sugarcane during 2005-06 and 2006-07

\begin{tabular}{|c|c|c|c|c|c|}
\hline Year & Treatment & $\begin{array}{l}\text { Establishment } \\
\text { of settlings } \\
\left(\mathrm{x} 10^{3} \mathrm{ha}^{-1}\right)\end{array}$ & Tiller $\left(\mathrm{x} 10^{3} \mathrm{ha}^{-1}\right)$ & $\begin{array}{l}\text { Millable cane } \\
\quad\left(\times 10^{3} \mathrm{ha}^{-1}\right)\end{array}$ & $\begin{array}{c}\text { Yield } \\
\left.\left(\text { ton }^{-1}\right)\right)\end{array}$ \\
\hline \multirow{5}{*}{ 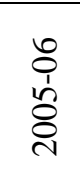 } & $\mathrm{I}_{1}$ & $22.55 \mathrm{~b}$ & $123.45 \mathrm{~b}$ & $93.73 b$ & $76.22 \mathrm{c}$ \\
\hline & $\mathrm{I}_{2}$ & $23.14 \mathrm{a}$ & $150.99 \mathrm{a}$ & $112.83 \mathrm{a}$ & $89.73 \mathrm{~b}$ \\
\hline & $\mathrm{I}_{3}$ & $23.39 \mathrm{a}$ & $152.30 \mathrm{a}$ & $117.56 \mathrm{a}$ & $99.62 \mathrm{a}$ \\
\hline & $\mathrm{I}_{4}$ & $23.26 \mathrm{a}$ & $148.54 \mathrm{a}$ & $115.04 \mathrm{a}$ & $97.19 \mathrm{a}$ \\
\hline & LSD at $5 \%$ & 0.215 & 11.37 & 11.36 & 5.23 \\
\hline \multirow{5}{*}{ 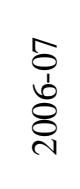 } & $\mathrm{I}_{1}$ & $23.18 \mathrm{~b}$ & 193.38 & $81.53 \mathrm{~b}$ & $72.63 \mathrm{~b}$ \\
\hline & $\mathrm{I}_{2}$ & $23.63 \mathrm{a}$ & 202.68 & $95.00 \mathrm{a}$ & $80.73 \mathrm{a}$ \\
\hline & $\mathrm{I}_{3}$ & $23.72 \mathrm{a}$ & 206.89 & $95.33 \mathrm{a}$ & $87.04 \mathrm{a}$ \\
\hline & $\mathrm{I}_{4}$ & $23.72 \mathrm{a}$ & 194.91 & $96.87 \mathrm{a}$ & $86.79 \mathrm{a}$ \\
\hline & LSD at $5 \%$ & 0.174 & ns & 9.91 & 7.56 \\
\hline
\end{tabular}

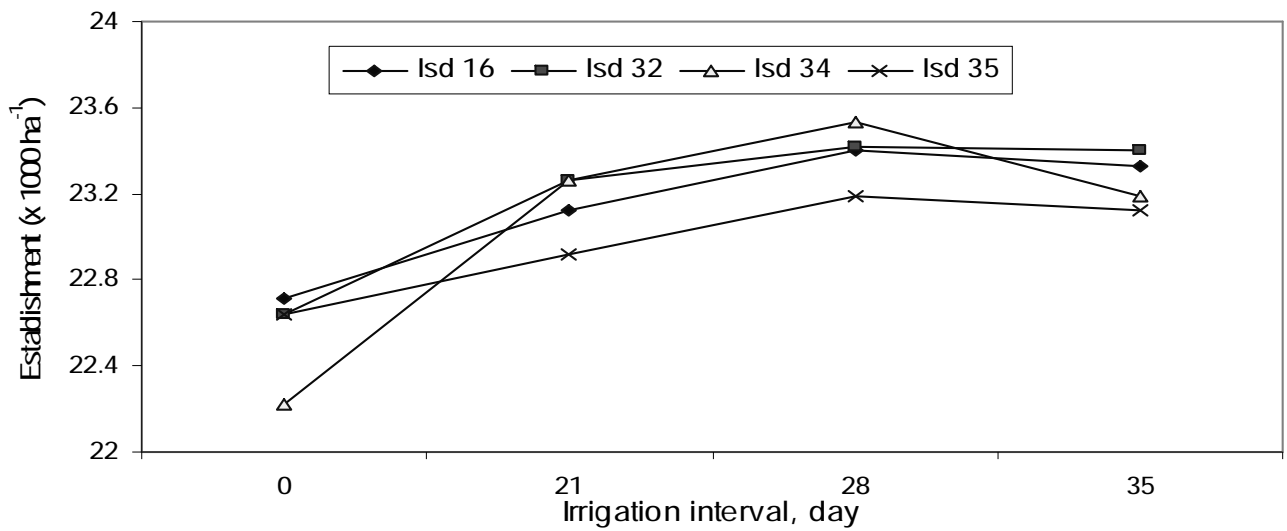

Figure 1. Establishment of settlings at different irrigation levels during 2005- 


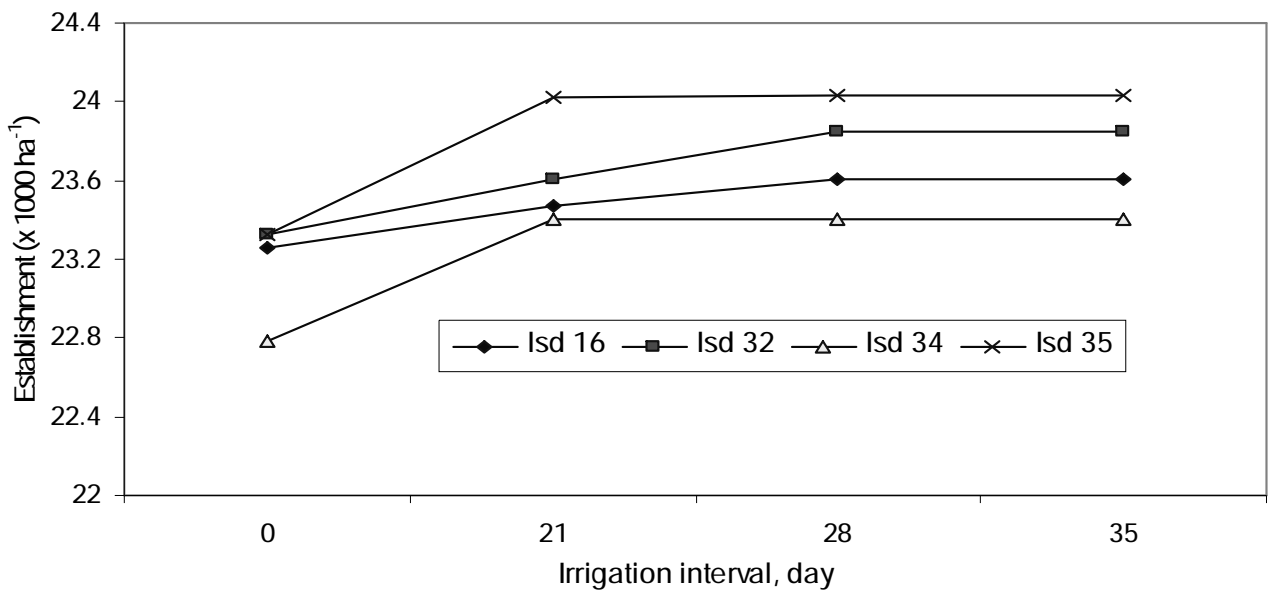

Figure 2. Establishment of settlings at different irrigation levels during 2006-07

The effect of irrigations on tiller production of each of the varieties during 2005-06 and 2006-07 has been shown in Figure 3 and 4, respectively. During 2005-06, the varieties $\mathrm{V}_{1}$ and $\mathrm{V}_{3}$ produced the highest number of tillers under treatment $\mathrm{I}_{2}$. The varieties $V_{2}$ and $V_{4}$ produced the highest number of tillers under treatment $\mathrm{I}_{3}$ (Figure 3). However, varieties $V_{2}, V_{3}$ and $V_{4}$ showed the best performance under treatment $\mathrm{I}_{3}$ except $\mathrm{V}_{1}$ which produced the highest number of tillers under $I_{2}$ treatment during 2006-07 (Figure 4). It is evident from both of the results that treatment $\mathrm{I}_{3}$ is the most responsive treatment for varieties $V_{2}, V_{3}$ and $\mathrm{V}_{4}$ and treatment $\mathrm{I}_{2}$ for variety $\mathrm{V}_{1}$.

\subsection{Millable Cane}

Millable cane is the number of sugarcane plants that are adequately matured for milling or crushing. The highest average number of millable cane was obtained from the treatment $\mathrm{I}_{3}$ $\left(117.56 \times 10^{3} \mathrm{ha}^{-1}\right)$ where irrigation was applied at 28 days interval in addition to two live irrigations at 0 and 14 DAP (Table 3). The lowest average millable canes were obtained from treatment $I_{1}\left(93.73 \times 10^{3} \mathrm{ha}^{-1}\right)$, where only two live irrigations were applied. Similar effects of irrigation were also observed during 2006-07.
The effects of irrigation on millable cane of each variety are shown in Figure 5 and 6 during 200506 and 2006-07, respectively. During 2005-06, variety $V_{1}$ showed the best performance in $I_{4}$ irrigation treatment, varieties $V_{2}$ and $V_{3}$ in $I_{3}$ and variety $V_{4}$ in $I_{2}$ (Figure 5). However, during 2006-07 cropping season, all the varieties they produced the highest number of millable cane under treatment $\mathrm{I}_{3}$, where irrigation was applied at 28 days interval in addition to two live irrigations at 0 and 14 DAP (Figure 6).

\subsection{Cane Yield}

Table 3 shows that irrigation had a positive impact on the yield of sugarcane. During 200506 the highest average yield of sugarcane was produced in treatment $\mathrm{I}_{3}\left(99.62 \mathrm{t} \mathrm{ha}^{-1}\right)$ where irrigation was applied at 28 days interval followed by treatment $\mathrm{I}_{4}\left(97.19 \mathrm{t} \mathrm{ha}^{-1}\right)$ and $\mathrm{I}_{2}$ $\left(89.73 \mathrm{tha}^{-1}\right)$ while the lowest average yield was in treatment $\mathrm{I}_{1}\left(76.22 \mathrm{t} \mathrm{ha}^{-1}\right)$. The difference in yield between treatments $\mathrm{I}_{3}$ and $\mathrm{I}_{4}$ were statistically insignificant. The average yield obtained from both the cropping seasons showed the same yield trend though there were some yield gaps between the two seasons. 


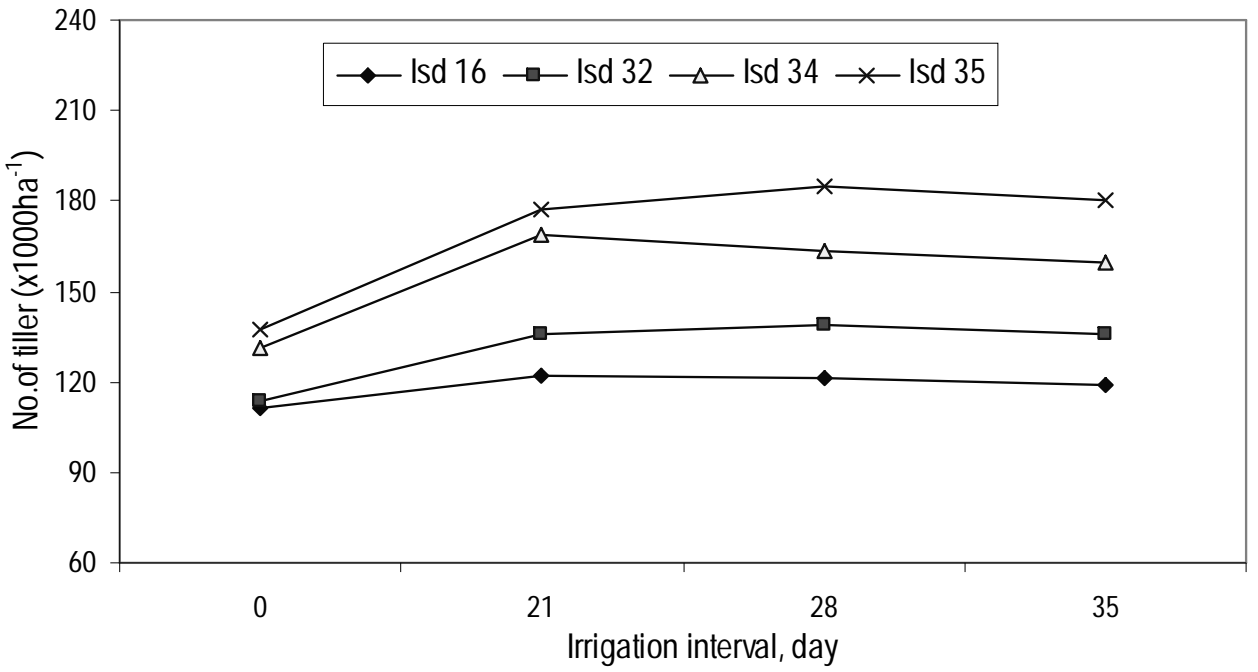

Figure 3. Number of tiller at different irrigation levels during 2005-06.

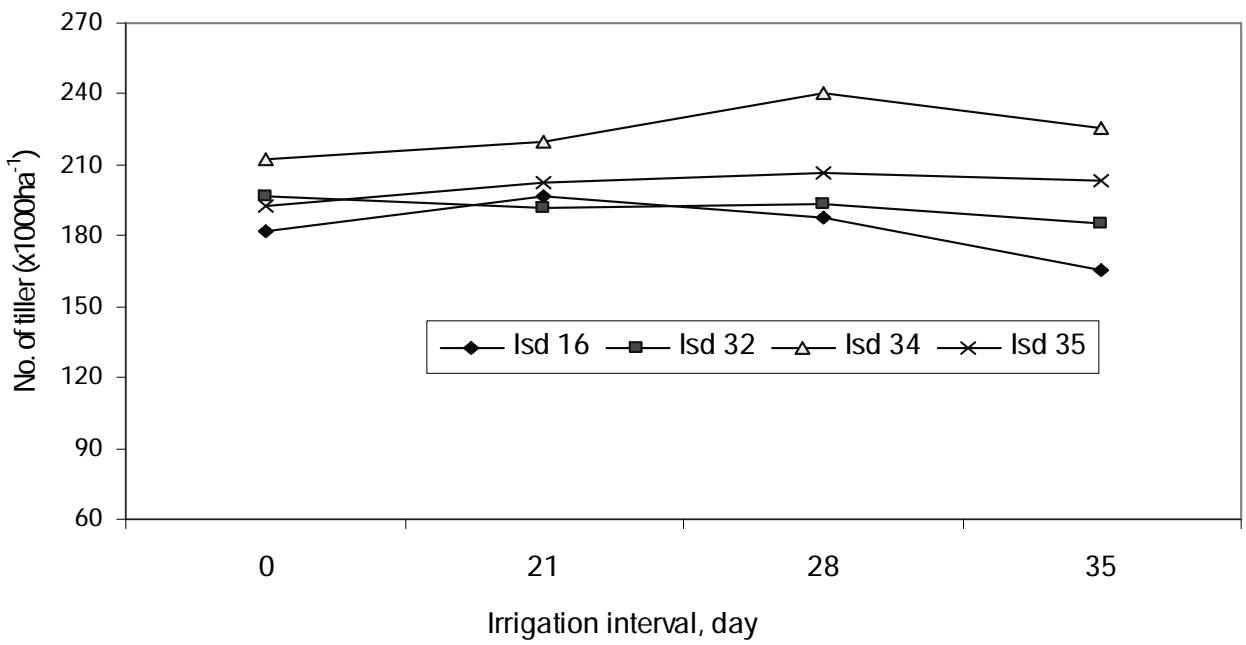

Figure 4. Number of tiller at different irrigation levels during 2006-07 


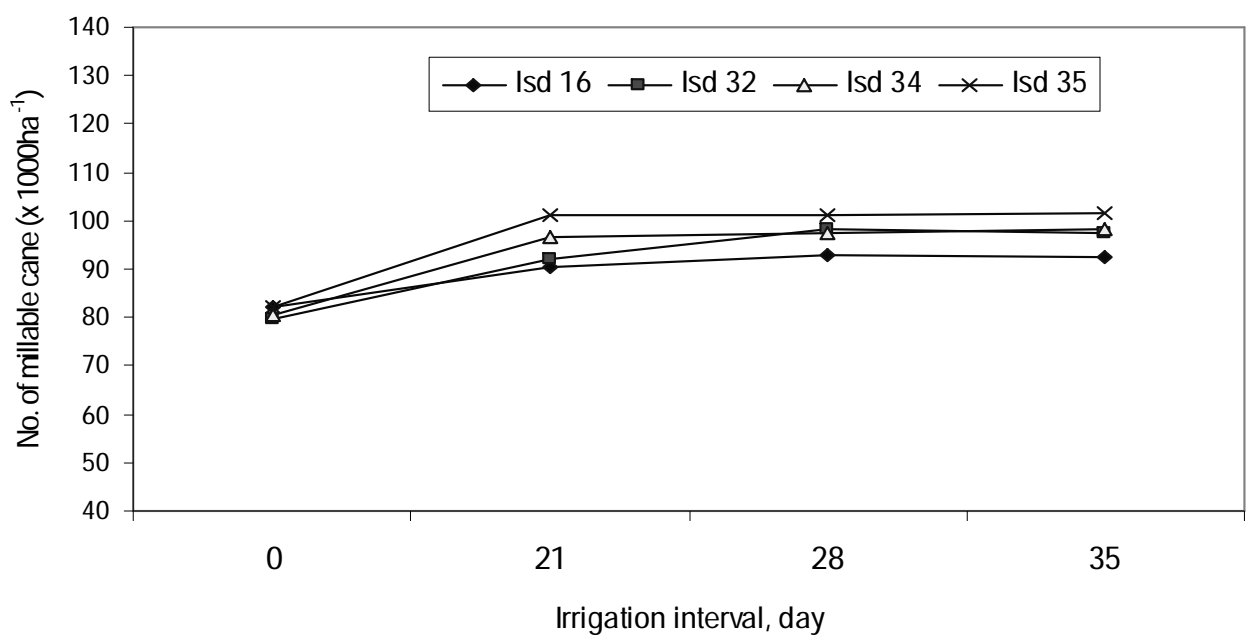

Figure 6. Number of millable cane at different irrigation levels during 2006-

07

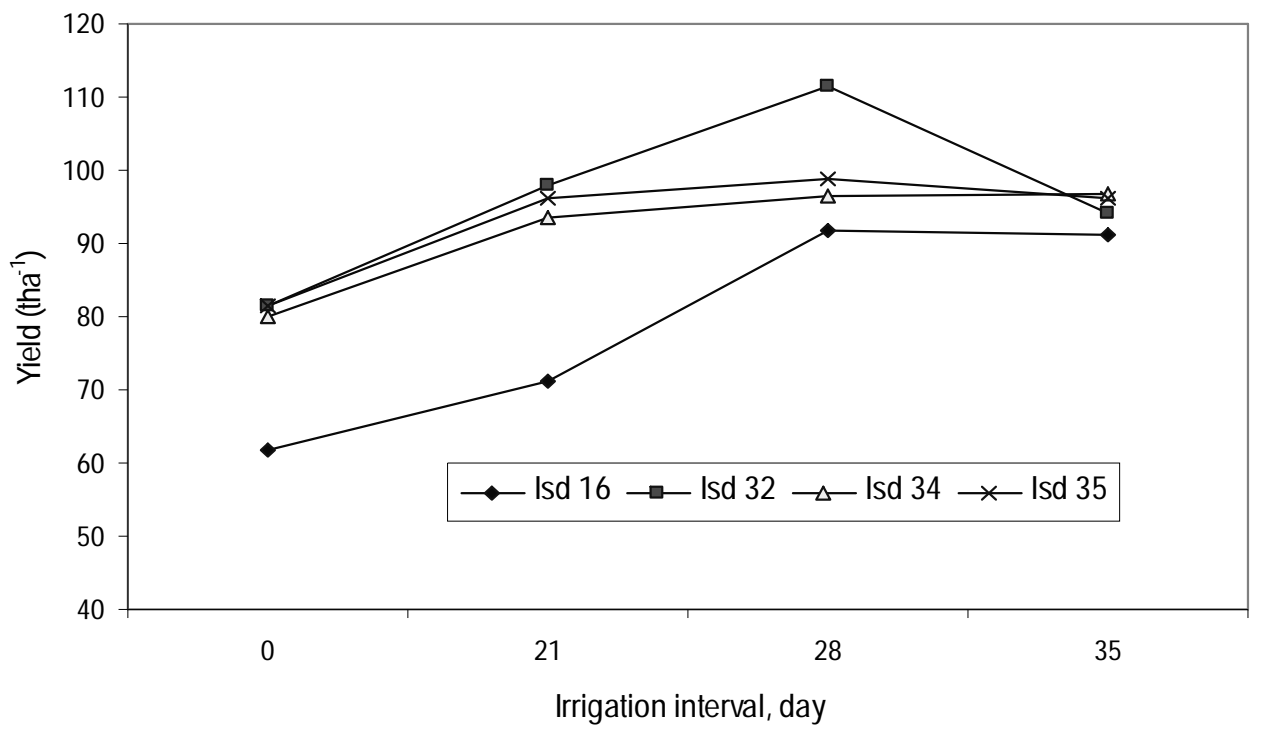

Figure 7. Yield of sgarcane at different irrigation levels during 2005-06 


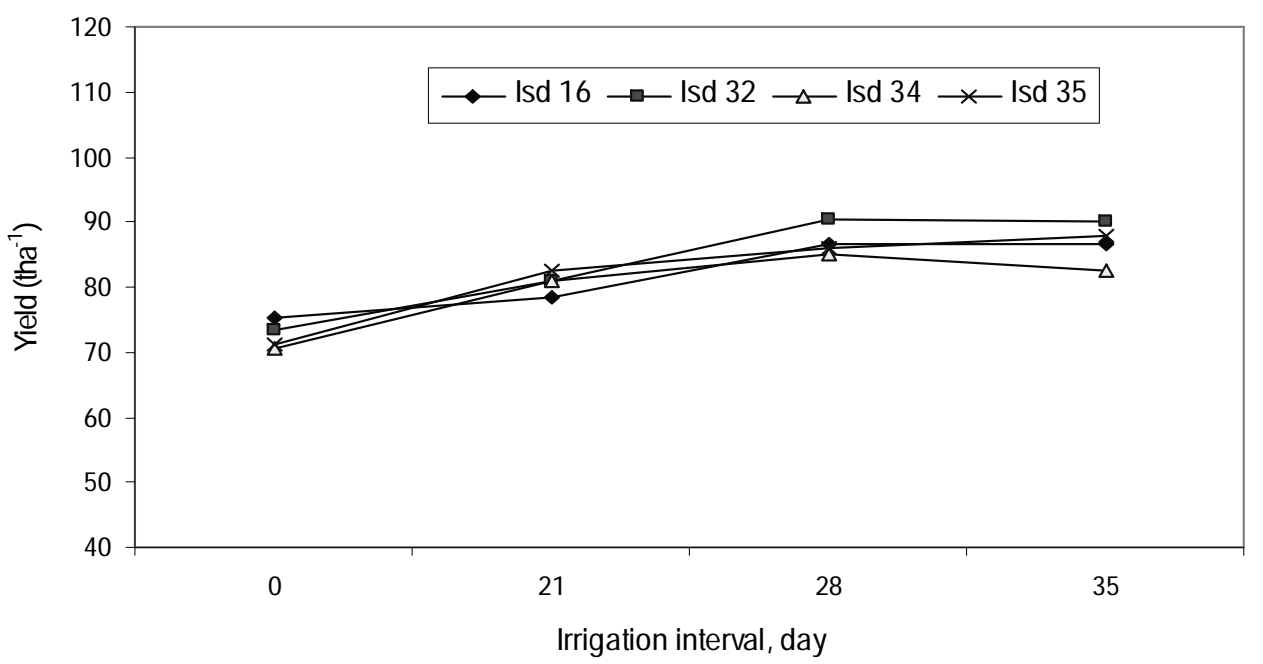

Figure 8. Yield of sugarcane at different irrigation levels during 2006-07

Similar effects of irrigation to increase yield was also found during 2006-07. The highest average yield of sugarcane was also produced in treatment $\mathrm{I}_{3}\left(86.19 \mathrm{t} \mathrm{ha}^{-1}\right)$, where irrigation was applied at 28 days interval followed by treatment $\mathrm{I}_{4}\left(86.79 \mathrm{t} \mathrm{ha}^{-1}\right)$ and $\mathrm{I}_{2}\left(80.73 \mathrm{t} \mathrm{ha}^{-1}\right)$. Rainfalls at the period of growth stages (May-September) of sugarcane much affected the treatments. So, average yield difference among treatments $I_{2}, I_{3}$, and $\mathrm{I}_{4}$ are statistically insignificant though the treatment $\mathrm{I}_{1}$ produced significantly lower yield (72. $63 \mathrm{t} \mathrm{ha}^{-1}$ ) than other treatments. It is important to mention that the average yield in all treatments during 2006-07 were lower than those during 2005-06, because of a remarkable number of plants were lost due to insects and diseases.

Figure 7 and 8 illustrate the effects of different irrigation levels on yield of different varieties during 2005-06 and 2006-07, respectively. Variety $\mathrm{V}_{1}$ during 2005-06 showed the best yield performance in irrigation treatment $I_{3}\left(91.73 \mathrm{tha}^{-}\right.$ ${ }^{1}$ ) (Figure 7).

However, variety $\mathrm{V}_{1}$ during 2006-07 cropping season showed the best performance in irrigation treatment $\mathrm{I}_{4}\left(86.76 \mathrm{t} \mathrm{ha}^{-1}\right)$ followed by $\mathrm{I}_{3}(86.63 \mathrm{t}$ $\mathrm{ha}^{-1}$ ) (Figure 8). Variety $\mathrm{V}_{2}$ during both the seasons gave the best yield in irrigation treatment $\mathrm{I}_{3}$, where yields were 111.59 and $90.47 \mathrm{t} \mathrm{ha}^{-1}$, respectively (Figure 7 \& Figure 8).

Variety $\mathrm{V}_{3}$ during 2005-06 cropping season showed the best yield performance in irrigation treatment $\mathrm{I}_{4}\left(96.74 \mathrm{t} \mathrm{ha}^{-1}\right)$ followed by treatment $\mathrm{I}_{3}$ (96.49 $\mathrm{t} \mathrm{ha}^{-1}$ ) (Figure 7). During 2006-07, variety $V_{3}$ gave the best yield in treatment $I_{3}$ $\left(85.13 \mathrm{t} \mathrm{ha}^{-1}\right)$ (Figure 8). Variety $\mathrm{V}_{4}$ during 200506 gave the best yield in treatment $\mathrm{I}_{3}$ (98.68 tha $\left.{ }^{1}\right)$, followed by treatment $\mathrm{I}_{4}\left(96.07 \mathrm{t} \mathrm{ha}^{-1}\right.$ ) (Figure 7). However, during 2006-07 cropping season, variety $\mathrm{V}_{4}$ gave the best yield in irrigation treatment $\mathrm{I}_{4}\left(87.80 \mathrm{t} \mathrm{ha}^{-1}\right)$, followed by treatment $\mathrm{I}_{3}\left(85.93 \mathrm{t} \mathrm{ha}^{-1}\right)$ (Figure 8).

\subsection{Interaction Effect}

The interaction effects of irrigation and variety on establishment of settings, tiller and millable cane production and cane yield during both the cropping seasons were statistically insignificant. Similar results were also reported by Hossain et al. (2008) in an experiment conducted at Ishurdi 
area of Bangladesh. However, variety $\mathrm{V}_{2}$ showed comparatively better performance (establishment and yield) in all the treatments combinations during both the cropping seasons. In general, $\mathrm{I}_{3} \mathrm{~V}_{1-4}$ treatment combination produced comparatively higher yield during both the cropping seasons.

\section{Conclusions}

It appeared that there were significant effects of irrigation on establishment of settlings, production of tiller and millable cane and cane yield of all the varieties. But, there was no evidence of effect of irrigation treatments on individual variety on establishment of settlings, tiller and millable cane production, and cane yield except the control treatment.

All the selected varieties (Isd 16, Isd 32, Isd 34, Isd 35) showed the best and almost similar yield response to irrigation treatments $\mathrm{I}_{3}$ and $\mathrm{I}_{4}$. From a conservative point of view, the treatment $\mathrm{I}_{3}$ where irrigation was applied at 28 days interval in addition to two live irrigations at 0 and 14 days after transplantation (DAP) may be recommended as optimum irrigation interval for all the selected varieties.

The selected varieties may be cultivated with potential yield in sandy loam soils of Chuadanga district in AZE-11 by applying 5 irrigations at 28 days interval in addition to two live irrigations at 0 and 10-14 DAP when soil bed budchip settlings are used as planting materials.

\section{References}

Anonymous. 1987. Water Management in Sugarcane. Indian Sugar. Vol. 37. No. 9:467-469.

BARC (Bangladesh Agricultural Research Council). 1989. Fertilizer recommendation guide. Soil publication No. 32, Published by the Bangladesh Agricultural Research Council, Farmgate, New Airport Road, Dhaka-1215, p.93.

Hossain, S.M.I., Eusufzai, S.U.K., and Rahman, M.A. 2008. Effect of Different Irrigation Levels on Growth and Yield of Sugarcane. Bangladesh Journal of Sugarcane, 30:51-61.

Hossain, S.M.I. 1992. Sugarcane irrigation in Bangladesh. The Bangladesh Observer, Dhaka, December 20, 1992, p. 4.

Husz, G.S. 1972. Sugarcane: Cultivation and Fertilisation, series of monographs on tropical and sub-tropical crops. Ruler Stickstoff, A.G. Bochun, West Germany.

Michael, A.M. 1991. Irrigation: Theory and Practice. Published by Vani Educational Books, New Delhi 110002, India. p.482

Rahman, A.B.M.; Ali, M.K. and Rahman, M.Kh. 1998. Sugarcane Cultivation: Technologies and Techniques (Bangla). Publication No. 74. Bangladesh Sugarcane Research Institute, Ishurdi, Pabna, Bangladesh, pp.11-22.

Rahman M. A., Eusufzai, S. U. K., Hossain, S. M. I. 2007. Varietal Performances of Budchip as Planting Materials for Sugarcane at Chuadanga Area., Bangladesh Journal Sugarcane, 29: 124 -128.

Shih, S.F., Myhre, D.L., Mishoe, J.W. and Kidder, G. 1977. Water management for sugarcane production in Florida Everglandes. Proc. Of International Society of Sugarcane Technologists (ISSCT). Vol. 2: 995-1008.

Srivastava, A.K. and Singh, K. 1987. Soil physical requirements for growing sugarcane. Indian Sugar. Vol.36, No. 12: 615-619. 